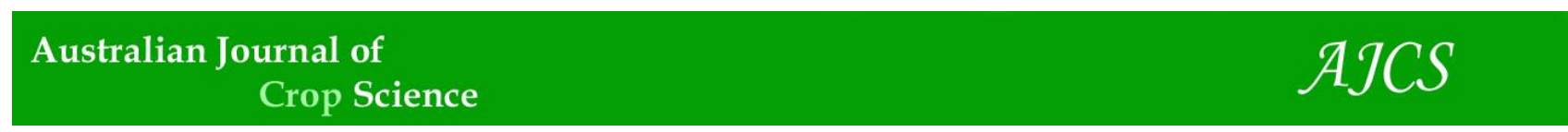

AJCS 11(11):1462-1468 (2017)

ISSN:1835-2707

doi: 10.21475/ajcs.17.11.11.pne637

\title{
Root growth and productivity of conventional and herbicide-tolerant canola in contrasting environments
}

\author{
Tânia Carla Mattioni ${ }^{1}$, Andréia Caverzan ${ }^{1}$, Saimom Sozo ${ }^{2}$, Gilberto Omar Tomm ${ }^{3}$, Geraldo \\ Chavarria $^{1^{*}}$
}

${ }^{1}$ Faculty of Agronomy and Veterinary Medicine, Agronomy Post-Graduate Program, University of Passo Fundo, Passo Fundo, Brazil

${ }^{2}$ Faculty of Agronomy and Veterinary Medicine, University of Passo Fundo, Passo Fundo, Brazil

${ }^{3}$ Brazilian Agricultural Research Corporation-Embrapa Wheat, Passo Fundo, Brazil

*Corresponding author: geraldochavarria@upf.br

\begin{abstract}
The canola (Brassica napus L. oil variant) is considered as a winter crop alternative in south Brazil. Thus, the aim of this study was to compare the root growth and the productivity components of hybrid grains of conventional and herbicide tolerant canola in different localities. The experiments were conducted in the municipality of Passo Fundo, Rio Grande do Sul state and Guarapuava, Paraná state, Brazil. The randomized block design with four replication was used. The genotypes evaluated were: Hyola 61 and H92002 (conventional), Hyola $571 \mathrm{CL}$ and K10050 (imidazolinone-resistant), and Hyola 751 TT (triazine-resistant). In order to evaluate the root system, soil monolith were collected and image analysis measuring the superficial area and the total root volume of the sample in diameter classes, root density and specific surface area were done. The grains productivity components and the number of branches in the plant were measured through the number of siliques in the branches. The productivity of the grains and the thousand grain mass were measured as well. The canola hybrid presented higher root length, surface area and volume in the diameter scale between 1 and $5 \mathrm{~mm}$ of density. In addition, there were variations in the growth of roots and grain productivity in different environments, in which imidazolinone-tolerant hybrids presented higher development of the roots, as well as, higher grain productivity in the different environment studied.
\end{abstract}

Keywords: Brassica napus L., roots, management, canola hybrids, grain productivity.

Abbreviations: DAS days after the sowing, GY grain yield, GUA Guarapuava, NSPB number of siliques in the primary branch, NSSB number of siliques in the secondary branch, NSTB number of siliques in the tertiary branch, PF Passo Fundo, PR Paraná, PAR photosynthetically active radiation, RS Rio Grande do Sul, SSA specific surface area, SA surface area, TGM thousand grain mass

\section{Introduction}

The canola (Brassica napus L. oil variant) is considered as a winter crop alternative in south Brazil, being the third most produced oleaginous plant worldwide, only overcome by African oil palm (Elaeis guineensis Jacq.) and soybean (Glycine max L.) (USDA, 2011). In Brazil, there are still technological difficulties that stop the canola production, such as the necessity of identifying sowing seasons for the regions with higher altitude, the proper management of the cultivation and the development of technologies to reduce harvest losses (Tomm, 2007). In addition, the lack of canola genotypes adapted to Brazil's edaphoclimatic conditions makes harder for the farmers to adopt this cultivation.

In South America, it is still not viable to use genetically modified herbicide-resistant canola cultivars for weed control due to the risk of crossing and incorporating the herbicide resistance to other Brassicaceae. The weed control is a significant concern between the canola growers (Oliver et al., 2016). Currently, hybrids with mutations, imidazolinone and triazine resistants, have been employed. In Australia, triazinetolerant varieties were first commercialised in 1993 and its introduction allowed the rapid expansion of production areas (Holtzapffel et al., 2008). One of the main benefits of herbicide tolerant canola is improved weed control, reduction of time and reduced tillage requirements (Shaw, 2014). Herbicide-tolerant crops have been adopted by farmers at countries where approved. In 2014, glyphosate-tolerant soybeans represented $50 \%$ of all herbicide-tolerant crops and about $80 \%$ of all globally cultivated soybeans (Bonny, 2016).

In 2015, triazine-tolerant varieties accounted for around $72 \%$ of canola grown in Western Australia (DAFWA, 2016). However, studies made abroad demonstrated that the process of using triazine-tolerant is associated with the reduction of the solar radiation conversion into biomass; that is an efficiency reduction in the use of solar radiation, which results in a reduced biomass production, in a reduction average of $10 \%$ to $15 \%$ in the grain yield and of $1 \%$ to $3 \%$ in the oil content, compared to conventional varieties. These results also demonstrate that triazine-tolerant genotypes are, generally, less vigorous, produce less biomass and present a delay in the crop development (Edwards and Hertel, 2011).

Hybrid genotypes have been making possible a new scenario for the canola production (Tomm, 2007). According to Edwards and Hertel (2011), hybrid variants are produced through controlled pollination; hence, the hybrid contains the best characteristics of both parents. In Brazil, it is still 
necessary the characterizing of the hybrids that adapt better to the edaphoclimatic conditions of the different regions of the country.

Well-adapted canola genotypes present high grain yield. For this, the root system is essential since besides the reserves accumulation and the anchorage, it is still responsible for water and nutrients absorption that supply the plant necessities. However, there are still few and little explored information about the canola root system. Studies about the roots development, their distribution, extension and activity are of extreme importance for understanding crop production and also influence of physical-chemical soil conditions. Such information may help in selecting hybrids that can better adapt to the different cultivation environments, minimizing risk associated with importation and the sowing of material without previous evaluation of the seeds adaptation to the local cultivation conditions.

This study aimed to compare the agronomical performance of five conventional and herbicide-tolerant canola genotypes, based on the evaluation of the root growth and the quantification of the components of grain yield in distinct cultivation sites.

\section{Results and discussion}

\section{Characterization of root system growth}

The canola hybrids showed differences for the root system variables at different cultivation places. The imidazolinonetolerant hybrids (Hyola $571 \mathrm{Cl}$ and $\mathrm{K}$ 10050) showed the higher surface area numbers in Guarapuava, presenting 8723.74 and $8711.06 \mathrm{~m}^{2} \mathrm{ha}^{-1}$, respectively. The numbers obtained in Guarapuava were higher than those of the experiment conducted in Passo Fundo (Table 1). On the other hand, in the same variable evaluation in Passo Fundo, the hybrid Hyola 571CL presented the smaller root surface area, evidencing a distinct response according to the cultivation location (Table 1).

The root surface area is very important to absorb water and nutrients from the soil (Edwards and Hertel, 2011). Dalmago et al. (2010) highlighted that there is heterogeneity of responses of the canola yield according to the environment. Thus, it is suggested that the higher numbers of the surface area of the hybrids in Guarapuava are due to the environmental conditions, which may be propitious for the canola, favoring a better development of the yield.

In the root volume evaluation, the numbers obtained in Guarapuava oscillated between 4.09 to $6.63 \mathrm{~m}^{3} \mathrm{ha}^{-1}$. The hybrids Hyola $571 \mathrm{Cl}$ and $\mathrm{K} 10050$ presented higher root volume (Table 1). In Passo Fundo's region, the oscillation of the results was higher, varying between 1.67 to $5.83 \mathrm{~m}^{3} \mathrm{ha}^{-1}$, and the higher root volume was achieved for hybrid $\mathrm{K} 10050$ (Table 1). Based on that, we claim that these hybrids present higher potential of competition for physical space due to the characteristics of larger surface area, root volume, water and nutrients, since they occupy a larger area of the soil. It is suggested that such hybrids can act as a tool in the biological control of infesting plants (Rizzardi et al., 2008), relying to the allelopathic action caused by glucosinolates in the roots (Uremis et al., 2009; Yasumoto et al., 2010),

A high importance is conferred to the specific surface area (SSA), as it is the contact between root and soil, responsible for the absorption of water and adsorption of cations. Russell (1977) argues that this is the most relevant characteristic for the absorption of small movable nutrients in the soil, such as phosphor and calcium for instance. Therefore, in
Guarapuava's experiment the highest numbers were presented by the hybrid Hyola 571CL, having higher SSA in Guarapuava's evaluation, when compared to the results obtained in Passo Fundo (Table 1).

On the contrary, for Passo Fundo's experiment, the hybrid Hyola 751TT presented the higher SSA, reaching $18.21 \mathrm{~m}^{2}$ $\mathrm{kg}^{-1}$ (Table 1). According to Lynch (2007), the little depth of the basal roots is an important characteristic for a better soil exploration and efficiency in phosphor acquisition in annual cultivations. In this way, plants of the hybrid Hyola 751TT with larger absorption area, can present a better nutritional state than those with smaller absorption area, besides having a higher tolerance to adverse environment conditions. Thus, the hybrid Hyola 571CL in Guarapuava as well as the hybrid Hyola 751TT in Passo Fundo can explore a larger area of the soil, which enlarges the possibility of accessing hydric and nutritional resources available in the soil profile.

For evaluation of the root dry mass, the values obtained in Guarapuava varied between 520.87 to $892.37 \mathrm{~kg} \mathrm{ha}^{-1}$, larger than those obtained in Passo Fundo, which oscillated between 301.76 to $651.03 \mathrm{~kg} \mathrm{ha}^{-1}$. We highlight that in both locations the hybrid $\mathrm{K} 10050$ showed the higher values of dry mass (Table 1). In cultivation system, where the aerial part of the plant is harvested for grain extraction, animal food or biofuel material, the part below the soil becomes the main contributor to the incorporation of carbon in the soil (Pietola and Alakukku, 2005). Thus, the high production of dry mass in root highlights that canola is an important alternative to incorporate the carbon in the soil compared to other crops such as wheat, which present an average of $410 \mathrm{~kg}^{-h^{-1}}$ of dry mass in the root (Gan et al., 2009).

For the root density, no difference was observed among genotypes at different locations, except for the hybrid Hyola 571CL, which presented a significant increase (of about a $100 \%$ ) on the root density in Passo Fundo, compared to results obtained in Guarapuava (Table 1). In a study conducted on Panicum maximum, the grazing stopped root growth and transference of the root's carbon to supply the growth necessities to the aerial part (Sarmento et al., 2008). Hence, we point out that the canola hybrids with higher root density such as the K 10050 and the H 92002 in Guarapuava and the Hyola 571CL in Passo Fundo, can present large quantities of reserve in the roots, being able to provide the carbon input necessary to the shoots in adverse conditions.

\section{Root surface area and root volume in diameter classes}

In relation to distribution of the surface area and the root volume in diameter classes, we observed that there is a major concentration of the roots in the class of 1-5 mm diameter in all hybrids evaluated for both yield locations (Table 2).

A significant increase in volume and root surface was noted in Guarapuava, compared to Passo Fundo, differing from the results obtained by Vercruyssen et al. (2011), which concluded that the phenotypical effects in root and growth of the shoots are mostly regulated by changes in genetic competence in optimal environment conditions and not by the source/drain regulation.

The hybrid Hyola 571CL concentrated approximately $32 \%$ of the root surface area in the diameter class of $<1 \mathrm{~mm}$ and $52 \%$ in the class of $1-5 \mathrm{~mm}$ (Table 2). The same hybrid presented a different response in the evaluation of the root volume, concentrating higher root volumes in the classes of $1-5$ and $5-$ 
Table 1. Characterization of root system growth of canola hybrids in distinct locations at $0-20 \mathrm{~cm}$ depth.

\begin{tabular}{|c|c|c|c|c|c|c|c|}
\hline \multicolumn{8}{|c|}{ SURFACE AREA $\left(\mathrm{m}^{2} \cdot \mathrm{ha}^{-1}\right)$} \\
\hline & Hyola 61 & Hyola 571CL & K 10050 & H 92002 & Hyola 751TT & Average & C.V. (\%) \\
\hline GUA & $7360.98 \mathrm{ABa}$ & $8723.74 \mathrm{Aa}$ & $8711.06 \mathrm{Aa}$ & $5183.25 \mathrm{Ca}$ & $5924.20 \mathrm{BCa}$ & \multirow{2}{*}{6370.09} & \multirow{2}{*}{10.00} \\
\hline $\mathrm{PF}$ & $5774.59 \mathrm{BCb}$ & $3362.32 \mathrm{Db}$ & $6952.88 \mathrm{ABb}$ & $5075.67 \mathrm{Ca}$ & $6632.24 \mathrm{ABa}$ & & \\
\hline \multicolumn{8}{|c|}{ VOLUME $\left(\mathrm{m}^{3} \cdot \mathrm{ha}^{-1}\right)$} \\
\hline & Hyola 61 & Hyola 571CL & K 10050 & H 92002 & Hyola 751TT & Average & C.V. $(\%)$ \\
\hline GUA & $5.66 \mathrm{Ba}$ & $6.63 \mathrm{Aa}$ & $6.03 \mathrm{ABa}$ & $4.09 \mathrm{Ca}$ & $4.21 \mathrm{Ca}$ & \multirow{2}{*}{4.45} & \multirow{2}{*}{8.19} \\
\hline $\mathrm{PF}$ & $3.53 \mathrm{BCb}$ & $1.67 \mathrm{Db}$ & $5.83 \mathrm{Aa}$ & $3.08 \mathrm{Cb}$ & $3.72 \mathrm{BCa}$ & & \\
\hline \multicolumn{8}{|c|}{ SPECIFIC SURFACE AREA $\left(\mathrm{m}^{2} \cdot \mathrm{kg}^{-1}\right)$} \\
\hline & Hyola 61 & Hyola 571CL & K 10050 & H 92002 & Hyola 751TT & Average & C.V. $(\%)$ \\
\hline GUA & $10.38 \mathrm{BCa}$ & $13.72 \mathrm{ABa}$ & $9.81 \mathrm{BCa}$ & $8.48 \mathrm{Ca}$ & $11.46 \mathrm{BCb}$ & \multirow{2}{*}{12.01} & \multirow{2}{*}{17.10} \\
\hline $\mathrm{PF}$ & $13.31 \mathrm{ABa}$ & $11.27 \mathrm{Bb}$ & $10.69 \mathrm{Ba}$ & $12.84 \mathrm{Ba}$ & $18.21 \mathrm{Aa}$ & & \\
\hline \multicolumn{8}{|c|}{ DRY MASS $\left(\mathrm{kg}^{\left.-\mathrm{ha}^{-1}\right)}\right.$} \\
\hline & Hyola 61 & Hyola 571CL & K 10050 & H 92002 & Hyola 751TT & Average & C.V. $(\%)$ \\
\hline GUA & $710.50 \mathrm{Ba}$ & $637.87 \mathrm{Ba}$ & $892.37 \mathrm{Aa}$ & $613.87 \mathrm{BCa}$ & $520.87 \mathrm{Ca}$ & \multirow{2}{*}{5.53} & \multirow{2}{*}{7.94} \\
\hline $\mathrm{PF}$ & $436.17 \mathrm{BCb}$ & $301.76 \mathrm{Db}$ & $651.03 \mathrm{Ab}$ & $399.12 \mathrm{CDb}$ & $368.82 \mathrm{CDb}$ & & \\
\hline \multicolumn{8}{|c|}{ DENSITY (kg.m³) } \\
\hline & Hyola 61 & Hyola 571CL & K 10050 & H 92002 & Hyola 751TT & Average & C.V. (\%) \\
\hline GUA & $125.63 \mathrm{BCa}$ & $96.37 \mathrm{Cb}$ & $149.97 \mathrm{ABa}$ & $150.95 \mathrm{ABa}$ & $124.64 \mathrm{BCa}$ & \multirow{2}{*}{129.41} & \multirow{2}{*}{12.26} \\
\hline $\mathrm{PF}$ & 123.50 BCDa & $181.50 \mathrm{Aa}$ & $111.60 \mathrm{CDa}$ & 130.39 BCDa & $99.53 \mathrm{Da}$ & & \\
\hline
\end{tabular}

Table 2. Root surface area $\left(\mathrm{m}^{2} \cdot \mathrm{ha}^{-1}\right)$ and root volume $\left(\mathrm{m}^{3} \cdot \mathrm{ha}^{-1}\right)$ in diameter class in canola hybrids in distinct locations. ROOT SURFACE AREA $\left(\mathrm{m}^{2} \cdot \mathrm{ha}^{-1}\right)$

\begin{tabular}{|c|c|c|c|c|c|c|c|}
\hline \multicolumn{8}{|c|}{$<1 \mathrm{~mm}$} \\
\hline & Hyola 61 & Hyola 571CL & K 10050 & H 92002 & Hyola 751TT & Average & C.V. (\%) \\
\hline GUA & $191.56 \mathrm{DB}$ & $2808.20 \mathrm{Aa}$ & 514.74B Ca & $255.88 \mathrm{CDb}$ & $664.94 \mathrm{Bb}$ & \multirow{2}{*}{1055.98} & \multirow{2}{*}{17.63} \\
\hline $\mathrm{PF}$ & $1496.12 \mathrm{Aa}$ & $739.62 \mathrm{Bb}$ & $456.34 \mathrm{Ba}$ & $1611.05 \mathrm{Aa}$ & $1819.63 \mathrm{Aa}$ & & \\
\hline \multicolumn{8}{|c|}{$1-5 \mathrm{~mm}$} \\
\hline & Hyola 61 & Hyola 571CL & K 10050 & H 92002 & Hyola 751TT & Average & C.V. (\%) \\
\hline GUA & $5868.19 \mathrm{ABa}$ & $4518.48 \mathrm{BCa}$ & $7103.95 \mathrm{Aa}$ & $4043.98 \mathrm{Ca}$ & $4469.22 \mathrm{Ca}$ & \multirow{2}{*}{4484.3} & \multirow{2}{*}{12.74} \\
\hline $\mathrm{PF}$ & $3806.94 \mathrm{BCb}$ & $2454.31 \mathrm{Cb}$ & $5245.70 \mathrm{Ab}$ & $2934.24 \mathrm{Ca}$ & $4397.91 \mathrm{ABa}$ & & \\
\hline \multicolumn{8}{|c|}{$5-10 \mathrm{~mm}$} \\
\hline & Hyola 61 & Hyola 571CL & K 10050 & H 92002 & Hyola 751TT & Average & C.V. $(\%)$ \\
\hline GUA & $1016.54 \mathrm{ABa}$ & $1092.15 \mathrm{Aa}$ & $941.79 \mathrm{Ba}$ & $607.43 \mathrm{Ca}$ & $614.59 \mathrm{Ca}$ & \multirow{2}{*}{671.41} & \multirow{2}{*}{8.97} \\
\hline $\mathrm{PF}$ & $411.36 \mathrm{Bb}$ & $157.41 \mathrm{Cb}$ & $1044.67 \mathrm{Aa}$ & $470.49 \mathrm{Ba}$ & $357.77 \mathrm{Bb}$ & & \\
\hline \multicolumn{8}{|c|}{$>10 \mathrm{~mm}$} \\
\hline & Hyola 61 & Hyola 571CL & K 10050 & H 92002 & Hyola 751TT & Average & C.V. $(\%)$ \\
\hline GUA & $284.70 \mathrm{Aa}$ & $304.50 \mathrm{Aa}$ & $150.58 \mathrm{Bb}$ & $275.96 \mathrm{Aa}$ & $175.41 \mathrm{Ba}$ & \multirow{2}{*}{158.41} & \multirow{2}{*}{13.29} \\
\hline $\mathrm{PF}$ & $58.37 \mathrm{Bb}$ & $10.88 \mathrm{Bb}$ & $206.30 \mathrm{Aa}$ & $60.41 \mathrm{Bb}$ & $56.95 \mathrm{Bb}$ & & \\
\hline \multicolumn{8}{|c|}{ ROOT VOLUME $\left(\mathrm{m}^{3} \cdot \mathrm{ha}^{-1}\right)$} \\
\hline \multicolumn{8}{|c|}{$<1 \mathrm{~mm}$} \\
\hline & Hyola 61 & Hyola571CL & K 10050 & H 92002 & Hyola751TT & Average & C.V. (\%) \\
\hline GUA & $0.036 \mathrm{Db}$ & $0.334 \mathrm{Aa}$ & $0.117 \mathrm{BCa}$ & $0.054 \mathrm{CDb}$ & $0.149 \mathrm{BCb}$ & \multirow[b]{2}{*}{0.21} & \multirow{2}{*}{19.25} \\
\hline $\mathrm{PF}$ & $0.41 \mathrm{Aa}$ & $0.157 \mathrm{Bb}$ & $0.107 \mathrm{Ba}$ & $0.356 \mathrm{Aa}$ & $0.417 \mathrm{Aa}$ & & \\
\hline \multicolumn{8}{|c|}{$1-5 \mathrm{~mm}$} \\
\hline & Hyola 61 & Hyola 571CL & K 10050 & H 92002 & Hyola 751TT & Average & C.V. $(\%)$ \\
\hline GUA & $2.99 \mathrm{BCa}$ & $3.065 \mathrm{ABa}$ & $3.744 \mathrm{Aa}$ & $2.116 \mathrm{Da}$ & $2.363 \mathrm{CDa}$ & \multirow{2}{*}{2.51} & \multirow{2}{*}{11.33} \\
\hline $\mathrm{PF}$ & $2.23 \mathrm{Bb}$ & $1.237 \mathrm{Cb}$ & $3.145 \mathrm{Aa}$ & $1.771 \mathrm{BCa}$ & $2.452 \mathrm{ABa}$ & & \\
\hline \multicolumn{8}{|c|}{$5-10 \mathrm{~mm}$} \\
\hline & Hyola 61 & Hyola 571CL & K 10050 & H 92002 & Hyola 751TT & Average & C.V. (\%) \\
\hline GUA & $1.747 \mathrm{ABa}$ & $2.138 \mathrm{Aa}$ & $1.660 \mathrm{Ba}$ & $1.028 \mathrm{Ca}$ & $1.135 \mathrm{Ca}$ & \multirow{2}{*}{1.19} & \multirow{2}{*}{15.62} \\
\hline PF & $0.712 \mathrm{BCb}$ & $0.242 \mathrm{Db}$ & $1.868 \mathrm{Aa}$ & $0.784 \mathrm{BCa}$ & $0.605 \mathrm{CDb}$ & & \\
\hline \multicolumn{8}{|c|}{$>10 \mathrm{~mm}$} \\
\hline & Hyola 61 & Hyola 571CL & K 10050 & H 92002 & Hyola 751TT & Average & C.V. (\%) \\
\hline GUA & $0.883 \mathrm{Aa}$ & $1.093 \mathrm{Aa}$ & $0.455 \mathrm{Ba}$ & $0.894 \mathrm{Aa}$ & $0.559 \mathrm{Ba}$ & \multirow{2}{*}{0.53} & \multirow{2}{*}{17.44} \\
\hline $\mathrm{PF}$ & $0.173 \mathrm{BCb}$ & $0.024 \mathrm{Cb}$ & $0.712 \mathrm{Aa}$ & $0.168 \mathrm{BCb}$ & $0.251 \mathrm{Bb}$ & & \\
\hline
\end{tabular}


Table 3. Grain yield components and final productivity of canola hybrids in distinct locations.

\begin{tabular}{|c|c|c|c|c|c|c|c|}
\hline \multicolumn{8}{|c|}{ NSPB (un.) } \\
\hline & Hyola 61 & Hyola 571CL & K 10050 & H 92002 & Hyola 751TT & Average & C.V. (\%) \\
\hline GUA & $64.78 \mathrm{Aa}$ & $50.87 \mathrm{BCa}$ & $52.56 \mathrm{Ba}$ & $45.38 \mathrm{Ca}$ & $49.92 \mathrm{BCa}$ & \multirow[b]{2}{*}{44.78} & \multirow[b]{2}{*}{5.61} \\
\hline $\mathrm{PF}$ & $40.23 \mathrm{BCb}$ & $36.00 \mathrm{CDb}$ & $47.96 \mathrm{Aa}$ & $29.86 \mathrm{~Eb}$ & $30.2 \mathrm{DEb}$ & & \\
\hline \multicolumn{8}{|c|}{ NSSB (un.) } \\
\hline & Hyola 61 & Hyola 571CL & K 10050 & H 92002 & Hyola 751TT & Average & C.V. (\%) \\
\hline GUA & $136.58 \mathrm{Aa}$ & $104.11 \mathrm{Ba}$ & $127.32 \mathrm{Aa}$ & $89.65 \mathrm{Ca}$ & $106.34 \mathrm{Ba}$ & \multirow{2}{*}{105.25} & \multirow{2}{*}{5.61} \\
\hline PF & $111.41 \mathrm{Bb}$ & $101.46 \mathrm{BCa}$ & $114.27 \mathrm{ABa}$ & $91.54 \mathrm{Ca}$ & $69.77 \mathrm{Db}$ & & \\
\hline \multicolumn{8}{|c|}{ NSTB (un.) } \\
\hline & Hyola 61 & Hyola 571CL & K 10050 & H 92002 & Hyola 751TT & Average & C.V. (\%) \\
\hline GUA & $55.54 \mathrm{Bb}$ & $44.40 \mathrm{Cb}$ & $65.19 \mathrm{Ab}$ & $28.04 \mathrm{Db}$ & $31.04 \mathrm{Da}$ & \multirow{2}{*}{60.75} & \multirow{2}{*}{6.02} \\
\hline $\mathrm{PF}$ & $68.29 \mathrm{Ca}$ & $78.43 \mathrm{Ba}$ & $136.33 \mathrm{Aa}$ & $66.11 \mathrm{Ca}$ & $34.12 \mathrm{Da}$ & & \\
\hline \multicolumn{8}{|c|}{ TOTAL NS (un.) } \\
\hline & Hyola 61 & Hyola 571CL & K 10050 & H 92002 & Hyola 751TT & Average & C.V. (\%) \\
\hline GUA & $256.91 \mathrm{Aa}$ & $199.37 \mathrm{BCa}$ & $245.07 \mathrm{Ab}$ & $163.08 \mathrm{Db}$ & $187.30 \mathrm{Ca}$ & \multirow{2}{*}{210.78} & \multirow{2}{*}{4.18} \\
\hline PF & $219.93 \mathrm{Bb}$ & $215.90 \mathrm{Ba}$ & $298.56 \mathrm{Aa}$ & $187.61 \mathrm{Ca}$ & $134.10 \mathrm{Db}$ & & \\
\hline \multicolumn{8}{|c|}{ TGM $(\mathrm{g})$} \\
\hline & Hyola 61 & Hyola 571CL & K 10050 & H 92002 & Hyola 751TT & Average & C.V. (\%) \\
\hline GUA & $3.42 \mathrm{Ba}$ & $3.50 \mathrm{Ba}$ & $3.92 \mathrm{Aa}$ & $3.42 \mathrm{Ba}$ & $3.25 \mathrm{Ca}$ & \multirow{2}{*}{3.17} & \multirow{2}{*}{7.69} \\
\hline $\mathrm{PF}$ & $2.57 \mathrm{Cb}$ & $3.31 \mathrm{Bb}$ & $3.51 \mathrm{Ab}$ & $2.47 \mathrm{Cb}$ & $2.41 \mathrm{Cb}$ & & \\
\hline \multicolumn{8}{|c|}{$\mathrm{GY} * *\left(\mathrm{~kg} \cdot \mathrm{ha}^{-1}\right)$} \\
\hline & Hyola 61 & Hyola 571CL & K 10050 & H 92002 & Hyola 751TT & Average & C.V. $(\%)$ \\
\hline GUA & $2042 \mathrm{AB}$ & $2799 \mathrm{AB}$ & $2840 \mathrm{~A}$ & $2359 \mathrm{AB}$ & $1853 \mathrm{AB}$ & \multirow{2}{*}{1873.9} & \multirow{2}{*}{15.12} \\
\hline PF & $1278 \mathrm{~B}$ & $1363 \mathrm{~B}$ & $1709 \mathrm{~A}$ & $1302 \mathrm{~B}$ & $1260 \mathrm{~B}$ & & \\
\hline
\end{tabular}

$10 \mathrm{~mm}$ of diameter. We highlight that the root architecture, which means the shape that root distributes in space, is genetically controlled, which can be reflected in the formation of adventitious and lateral roots, length and root density (Lynch, 2007).

Nevertheless, the hybrid K 10050 , produced approximately $90 \%$ of its surface area and root volume with narrowintermediate and large-intermediate roots, meaning the diameter classes of $1-5$ and $5-10 \mathrm{~mm}$ (Table 2). The abundance of narrow canola roots is related to the ramification capacity and proliferation in areas with higher concentration of nutrients (Edwards and Hertel, 2011). The larger roots (with larger diameter) are attributed to more resistance and by that the possibility of penetrating into more compact layers, then increasing the bioporosity and the soil mesofauna, which is the reason for considering fundamental the crop rotation (Stone et al., 2006). Generally, roots of dicotyledon plants with a larger diameter penetrate more than the roots of monocotyledon species (Materechera et al., 1991). According to Edwards and Hertel (2011), the root system of mature canola plants can penetrate deeply to reach even $120 \mathrm{~cm}$ in the soil. In addition, roots with augmented diameter have large xylem vessels, increasing axial conductance and improving the penetration capacity of rice roots (Oryza sativa L.) (Fukai and Cooper, 1995; Clark et al., 2008). Thus, it is highlighted that the hybrid K 10050 is an option for crop rotation, helping to improve soil conditions.

According to Casão Junior et al. (2000) in the tillage system, the seeders equipped with cutting blades and spade plows break up the compacted layers of soil close to the surface. The breakup of the compacted layers favors the development of pivoting canola roots and these contribute in the formation of macropores, which in their part contribute to water aeration and infiltration in the soil. Thus, the hybrids Hyola 571CL in Guarapuava, and K 10050 in Passo Fundo presented themselves as alternative tools to be used in tillage system acting in the process of biological scarification of soil, since they potential characteristics of the root system.

\section{Grain yield components and final productivity}

In respect to the number of siliques in the primary branch (NSPB), the hybrid Hyola 61 obtained the best NSPB, reaching 64.78 siliques at Guarapuava, obtaining a better result than Passo Fundo location. In Passo Fundo, the higher NSPB was obtained by the hybrid K 10050, reaching 47.96 siliques.

In relation to number of siliques in the secondary branch (NSSB) in Guarapuava, the hybrid Hyola 61 and the hybrid K 10050 produced the best NSSB, 136.58 and 127.32, respectively (Table 3 ). For the same variable in Passo Fundo, the hybrid K 10050 also produced the best NSSB (114.27 siliques).

For the variable number of siliques in the tertiary branch (NSTB), the hybrid K 10050 showed the best results in both locations, reaching 65.19 siliques in Guarapuava and 136.33 siliques in Passo Fundo's evaluation. Hence, the result for this variable in Passo Fundo was higher than in Guarapuava (Table 3). The distinct responses of the evaluated hybrids in this study may proceed from environmental influence not only in the branch emission (Krüger et al., 2011), but also in the number of siliques emitted by plant (Mousavi et al., 2011), consisting in a physiological strategy of the plant for a better light gathering (Dalmago et al., 2013).

In general, we observe that the hybrid K 10050 obtained the highest number of siliques in the plant (NSSB and NSTB) in both yield locations compared to the other hybrids (Table 3 ). The average values obtained for the number of siliques per plant were similar in both yield locations, close to 210 (Table 3), corroborating with data already observed, in which the number of siliques per plant was close to 200 (ElNakhlawy and Bakhashwain, 2009). 
Regarding the variable thousand grain mass (TGM), the hybrid K 10050 presented higher values, reaching 3.91g in Guarapuava and 3.51g in Passo Fundo. Therefore, for this hybrid the result obtained in Guarapuava surpassed the Passo Fundo (Table 3). This result corroborates with previous data that pointed out the values of $3.8 \mathrm{~g}$ (Kamkar et al., 2011). The TGM of the hybrids cultivated in Guarapuava presented, in general, an increase of $22 \%$ when compared to the results obtained in Passo Fundo (Table 3). Although, this variable is genetically determined but environmental factors still affect it (Pandey and Torri, 1973). This may be associated with the lower levels of photosynthetically active radiation (PAR) observed in the period (data not presented) in Passo Fundo. Therefore, the fact that the locations evaluated presented different conditions for canola production justifies the variation verified in the TGM in the different locations. We highlight that the TGM is a component of yield productivity that has major stability; since, in order to compensate deficiencies, the plant decreases the number of siliques per plant to give more support to the final grain filling process (Silva et al., 2011).

To variable grain yield (GY), an increase of about $70 \%$ was observed in Guarapuava's evaluation, when compared to Passo Fundo's. The hybrid K 10050 obtained the larger GY in both yield locations, surpassing the other evaluated hybrids, reaching $2.840 \mathrm{~kg} \mathrm{ha}^{-1}$ in Guarapuava and $1.709 \mathrm{~kg}$ $\mathrm{ha}^{-1}$ in Passo Fundo (Table 3). It is highlighted that the production ceiling in both yield locations surpassed the national averages of grain yield close to $1.330 \mathrm{~kg} \mathrm{ha}^{-1}$ (CONAB, 2013). The grain yield obtained in Passo Fundo reached the results obtained by Krüger et al. (2011) and Bandeira et al. (2013), which obtained 1.381 and $1.195 \mathrm{~kg}$ $\mathrm{ha}^{-1}$, respectively.

Environmental factors such as temperature, humidity, light and nutrition are related to the growth regulation and to the development of canola plants (Edwards and Hertel, 2011), consequently affecting the production. Studies demonstrated that the grain yield obtained in canola with the use of irrigation varied between 2.200 to $3.200 \mathrm{~kg} \mathrm{ha}^{-1}$ (TohidiMoghadam et al., 2009). It should be noted that the grain yield values obtained with irrigated canola were reached by Guarapuava's experiment without the use of irrigation for the hybrids studied (Table 3). This suggests that the location presents the necessary conditions for canola cultivation development and that the hybrids used present adaptation to local edaphoclimatic conditions.

\section{Materials and methods}

\section{Experimental conditions}

The experiments were obtained through field research in two different places: (1) the municipality of Guarapuava, Paraná state (PR), Brazil; (2) the municipality of Passo Fundo, Rio Grande do Sul state (RS), Brazil.

In Guarapuava, the experiment was settled in experimental area (latitude $25^{\circ} 55^{\prime} \mathrm{S}$, longitude $51^{\circ} 48^{\prime} \mathrm{W}$ and altitude of 1.110 meters). The soil is classified as typical clayey aluminic Oxisol. The sowing took place on May $2^{\text {nd }}, 2014$, after a soybean production. A plot seeder was used, in which each plot constituted of four rows with $0.4 \mathrm{~m}$ width between each row. The evaluated canola hybrids emerged on May $10^{\text {th }}, 2014$, eight days after the sowing (DAS).

In Passo Fundo, the experiment was set up in experimental area (latitude $28^{\circ} 15^{\prime} \mathrm{S}$, longitude $52^{\circ} 24^{\prime} \mathrm{O}$, and altitude of 687 meters). The soil is classified as dystrophic red oxisol humic. The sowing of the canola hybrids was conducted on on April $28^{\text {th }}, 2014$ manually, succeeding the cultivation of Sorghum sudanense. The emergence date was May $7^{\text {th }}, 2014$, 10 DAS. The width between rows used was of $0.34 \mathrm{~m}$.

In both experiments, the base fertilization and topdressing were made according to the recommendations and also based on the soil analysis. Insecticide applications for pest control and herbicide for weed control were made during the crop cycle.

\section{Experimental design}

Five canola hybrids were evaluated; two conventional hybrids (Hyola 61 and $\mathrm{H}$ 92002) and two imidazolinonetolerant hybrids (Hyola $571 \mathrm{Cl}$ and $\mathrm{K} 10050$ ) and triazinetolerant hybrid (Hyola 751TT). The experimental design was the randomized block design with four repetitions.

\section{Root system assessments}

In order to evaluate the roots, a sample collection was taken in the form of a monolith of the known area, following Böhm (1979). The samples were of $0.5 \mathrm{~m}$ linear and depth of $0-20$ $\mathrm{cm}$. The width was determined by the measurement of the distance between rows used, being half of the measure for each side of the sowing line. Thus, we used a $0.4 \mathrm{~m}$ width in Guarapuava and $0.34 \mathrm{~m}$ in Passo Fundo. The following variables of the root were evaluated: surface area (SA) $\left(\mathrm{m}^{2} \cdot \mathrm{ha}^{-1}\right)$, volume $\left(\mathrm{m}^{3} \cdot \mathrm{ha}^{-1}\right)$, specific surface area (SSA) $\left(\mathrm{m}^{2} \cdot \mathrm{kg}^{-1}\right)$, dry mass $\left(\mathrm{kg} \cdot \mathrm{ha}^{-1}\right)$ and density $\left(\mathrm{kg} \cdot \mathrm{m}^{-3}\right)$.

After soil monolith collection, the samples were bathed using two metallic tables that contain metallic sieves with distinct orifice diameter, the larger having more than $6.5 \mathrm{~mm}$ and the smaller with $1.5 \mathrm{~mm}$ of diameter. With the use of running water jets, the soil was removed from the sample, without fragmenting the roots during the process.

In order to evaluate the root sample, the image analysis method was used through the Sistema de Análises de Fibras e Raizes (Fibers and Roots Analysis System) - SAFIRA. In the software, the images were converted into binary codes to score/record the variables: root surface area and root total volume. Afterwards, these variables (surface area and root volume) were measured in established root diameter classes: $<1 \mathrm{~mm}$ (narrow), thickness between 1-5 mm (narrow intermediate), thickness between 5-10 mm (large intermediate), and thickness of $>10 \mathrm{~mm}$ (large) (adapted from Snowdon et al., 2000; Jesus et al., 2006).

\section{Dry mass of the root}

To obtain the dry mass of the root, the samples were dried in a hothouse at $60{ }^{\circ} \mathrm{C}$ for 72 hours. Based on the root volume and the root dry mass information, the density (correlation: dry mass/volume) and the specific surface area (correlation: surface area/dry mass) were estimated.

\section{Grain yield components}

In the grains physiological maturation stage, $50 \%$ of the seeds changed to the dark color in the siliques that are in the middle of the main raceme of the plants (Tomm, 2007). Ten plants from each plot were chosen randomly and root characteristic such as: number of siliques in the primary branch (NSPB), in the secondary branch (NSSB), and of tertiary branch (NSTB) were determined.

To obtain the grain yield in both locations, two central lines of each plot were manually collected with a sickle and grinded in a Wintersteiger ${ }^{\circledR}$ Plotseed. After adjusting the 
humidity percentage to $10 \%$, the grain yield (GY) $\left(\mathrm{kg} \cdot \mathrm{ha}^{-1}\right)$ was measured. The thousand grain mass (TGM) (g) was measured through counting and weighting.

\section{Statistical analysis}

The data was submitted to analysis of variance (ANOVA) and the averages were compared through the Turkey test at a $5 \%$ probability of error.

\section{Conclusion}

The study revealed the performance of canola hybrids in contrasting environments. The canola hybrids present higher length, surface area and volume in the roots in the diameter scale between 1 and $5 \mathrm{~mm}$ of thickness. Moreover, there are differences in the roots growth and grain yield in the different environments. The hybrid K 10050 shows greater roots development, shoots, as well as, higher grains yield in both studied locations. The increase of root dry mass influences the increase of leaf area and grain yield. In this study, the mutations that lead to herbicide tolerance are not impairment to vegetative growth and grain productivity in canola.

\section{Acknowledgements}

The authors are grateful to Coordenação de Aperfeiçoamento de Pessoal de Nível Superior (CAPES) for financial support. PNPD/CAPES for scholarship of Andréia Caverzan and CAPES for scholarship Tânia Carla Mattioni.

\section{References}

Bandeira TP, Chavarria G, Tomm GO (2013) Desempenho agronômico de canola em diferentes espaçamentos entre linhas e densidades de plantas. Pesq Agropec Bras. 48: 1332-1341.

Böhm W (1979) Methods of studying root systems. SpringerVerlag Berlin Heidelberg, New York.

Bonny S (2016) Genetically modified herbicide-tolerant crops, weeds, and herbicides: overview and impact. Environ Manage. 57: 31-48.

Casão Júnior R, Araújo AG, Ralish R (2000) Desempenho da semeadora-adubadora magnum 2850 em plantio direto no basalto paranaense. Pesq Agropec Bras. 35: 523-32.

Clark LJ, Price AH, Steele KA, Whalley RR (2008) Evidence from near-isogenic lines that root penetration increases with root diameter and bending stiffness in rice. Funct Plant Biol. 35: 1163-1171.

CONAB - Companhia nacional do abastecimento. Acompanhamento da safra brasileira de grãos 2012/2013 Décimo primeiro levantamento - setembro/2013. http://www.conab.gov.br/OlalaCMS/

uploads/arquivos/13_04_09_10_27_26_boletim_graos_abri 1_2013.pdf Accessed on the 22/01/2015.

DAFWA (2016) Canola variety guide for Western Australia 2017. Government of Western Australia, Bulletin 4877 https://www.agric.wa.gov.au/sites/gateway/files/DAFWA\% 20Canola\%20variety $\% 20$ guide\%202017.pdf Accessed on the 08/06/2017.

Dalmago GA, Cunha GR, Santi A, Pires JLF, Müller AL, Bolis LM (2010) Aclimatação ao frio e dano por geada em canola. Pesq Agropec Bras. 45: 933-943.

Dalmago GA, Fochesatto E, Kovaleski S, Tazzo IF, Bolis LM, Da Cunha GR, Nied AH, Bergamaschi H, Santi A (2013) Filocrono e número de folhas da canola em diferentes condições ambientais. Pesq Agropec Bras. 48: 573-581

Edwards J, Hertel K (2011) Procrop: Canola growth and development. Department of primary industries, New South Wales.

El-Nakhlawy FS, Bakhashwain AA (2009) Performance of canola (Brassica napus L.) seed yield, yield components and seed quality under the effects of four genotypes and nitrogen fertilizer rates. Met Env Arid Land Agric Sci. 20: 33-47.

Fukai S, Cooper M (1995) Development of drought-resistant cultivars using physio-morphological traits in rice. Field Crops Res. 40: 67-86.

Gan YT, Campbell CA, Janzen HH, Lemke R, Liu LP, Basnyat P, McDonald CL (2009) Root mass for oilseed and pulse crops: growth and distribution in the soil profile. Can J Plant Sci. 89: 883-893.

Holtzapffel R, Mewett O, Wesley V, Hattersley P (2008) Genetically modified crops: tools for insect pest and weed control in cotton and canola. Australian Government Bureau of Rural Sciences, Canberra. www.daff.gov.au/SiteCollectionDocuments/agfood/biotech/GM-crops-insect-pest-weed-control-26 1108.pdf Accessed on the 07/06/2017.

Jesus AMS, Carvalho SP, Soares ÂM (2006) Comparação entre sistemas radiculares de mudas de Coffea arabica $\mathrm{L}$. obtidas por estaquia e por sementes. Coffee Sci. 1: 14-20.

Kamkar B, Daneshmand AR, Ghooshchi F, Shiranirad AH, Safahanilangeoudi AR (2011) The effects of irrigation regimes and nitrogen rates on some agronomic traits of canola under semiarid environment. Agr Water Manag. 98: 1005-1012.

Krüger CAMB, Silva JAG, Medeiros SLP, Dalmago GA, Gaviraghi J (2011) Herdabilidade e correlação fenotípica de caracteres relacionados à produtividade de grãos e à morfologia da canola. Pesq Agropec Bras. 46: 1625-1632.

Lynch JP (2007) Roots of the second green revolution. Aust J Botany. 55: 493-512.

Materechera SA, Dexter AR, Alston AM (1991) Penetration of very strong soils by seedling roots of different plant species. Plant and Soil. 135: 31-41.

Mousavi JS, Sam-Daliri M, Bagheri H (2011) Study of planting density on some agronomic traits of three rapeseed cultivar (Brassica napus L.). Aust J Basic Appl Sci. 5: 2625-2627.

Oliver DP, Kookana RS, Miller RB, Correll RL (2016) Comparative environmental impact assessment of herbicides used on genetically modified and nongenetically modified herbicide-tolerant canola crops using two risk indicators. Sci Total Environ. 557-558: 754-763.

Pandey JP, Torri EJH (1973) Path coefficient analysis of seed yield components in soybean Glycine $\max (\mathrm{L})$ Merrill. Crop Sci. 13: 505-507.

Pietola L, Alakukku L (2005) Root growth dynamics and biomass input by Nordic anual field crops. Agric Ecosyst Environ. 108: 135-144.

Rizzardi MA, Neves R, Lamb TD, Johann LB (2008) Potencial alelopático da cultura da canola (Brassica napus L. var. oleífera) na supressão de picão-preto (Bidens sp.) e soja. Rev Bras Agroc. 14: 239-248.

Russell RS (1977) Plant root systems: their function and interaction with the soil. McGraw-Hill, London.

Sarmento P, Rodrigues LR De A, Lugão SMB, Da Cruz MCP, De Campos FP, Ferreira ME, De Oliveira RF (2008) Root system of Panicum maximum Jacq. cv. IPR-86 Milênio fertilized with nitrogen and submitted to rotational stocking. Rev Bras Zoot. 37: 27-34. 
Shaw DR (2014) The value of genetically-modified crops for weed control. Outlooks Pest Manag. 25: 36-37.

Da Silva JAG, Da Motta MD, Winch JA, Crestani M, Fernandes SBV, Berto JL, Gaviraghi F, Martins JAK, Wagner JF, Valentini APF, Zambonato F (2011) Dessecação em pré-colheita como estratégia de manejo na redução de perdas por fatores de ambiente em canola. Rev Bras Agroc. 17: 15-24.

Snowdon P, Eamus D, Gibbons P, Khanna P, Keith H, Raison J, Kirschbaum M (2000) Synthesis of allometrics, review of root biomass and design of future woody biomass sampling strategies. National Carbon Accounting System Technical Report, no. 17, Australia.

Stone LF, Silveira PM, Moreira JAA (2006) Atributos físicohídricos do solo sob plantio direto. Embrapa Arroz e Feijão, Santo Antônio do Goiás.

Tohidi-Moghadam HR, Shirani-Rad AH, Nour-Mohammadi G, Habibi D, Modarres-Sanavy SAM, Mashhadi-AkbarBoojar M, Dolatabadian A (2009). Response of six oilseed rape genotypes to water stress and hydrogel application. Pesq Agropec Trop. 39: 243-250.

Tomm GO (2007) Indicativos tecnológicos para produção de canola no Rio Grande do Sul. Embrapa Trigo, Passo Fundo.

Uremis I, Arslan M, Uludag A, Sangun M (2009) Allelopathic potentials of residues of 6 brassica species on johnsongrass [Sorghum halepense (L.). Pers]. Afr J Biotechnol. 8: 3497-3501.

USDA (2011) Oilseeds: World Market and Trade. In: Circular Series. Department of Agriculture, Foreign Agricultural Service, United States, p. 1-33.

Vercruyssen L, Gonzalez N, Werner T, Schmulling T, Inze D (2011) Combining enhanced root and shoot growth reveals cross talk between pathways that control plant organ size in Arabidopsis. Plant Physiol. 155: 1339-1352.

Yasumoto S, Matsuzakil M, Hirokane H, Okada K (2010) Glucosinolate content in rapeseed in relation to suppression of subsequent crop. Plant Prod Sci. 13: 150-155. 